\title{
Structural changes of polyethylene in blown films with different pro-oxidants
}

\author{
João Augusto Osório Brandão1* (iD, Fernando Dal Pont Morisso² (i), Edson Luiz Francisquetti ${ }^{3}$ \\ and Ruth Marlene Campomanes Santana ${ }^{1}$ (D)
}

\author{
'Departamento de Materiais, Universidade Federal do Rio Grande do Sul - UFRGS, Porto Alegre, RS, Brasil \\ ${ }^{2}$ Laboratório de Estudos Avançados de Materiais, Universidade Feevale, Novo Hamburgo, RS, Brasil \\ ${ }^{3}$ Departamento de Materiais, Instituto Federal do Rio Grande do Sul, Farroupilha, RS, Brasil \\ *jaobrandao@yahoo.com.br
}

\begin{abstract}
The accumulation of polymeric residues has been one of the most impacting environmental problems in recent human history, coming, above all, from disposable artefacts, such as plastic bags. Processing polyolefins with pro-oxidant additives is an alternative to favour the abiotic degradation process of macromolecules, including thermooxidation, so that the oxygenated fragments produced can be assimilated by microorganisms. The objective of this work was to evaluate the process of thermomechanical oxidative degradation of polyethylene (PE) during tubular extrusion of HDPE/LDPE films, without and with $1 \%$ of two different pro-oxidants, $\mathrm{d} 2 \mathrm{w}^{\mathrm{TM}}$ and benzoin. The results of viscosimetric and MFI analyses indicated smaller chain sizes in the additivated films. The FTIR spectra and contact angles indicate a higher presence of polar functional groups in the samples with pro-oxidants. The surface morphological analysis by SEM indicated difference of PE homogeneity in the films. Benzoin, however, proved to be a better pro-oxidant than $\mathrm{d} 2 \mathrm{w}^{\mathrm{TM}}$.
\end{abstract}

Keywords: benzoin, $d 2 w^{T M}$, polyethylene, pro-oxidants, thermooxidation.

How to cite: Brandão, J. A. O., Morisso, F. D. P., Francisquetti, E. L., \& Santana, R. M. C. (2021). Structural changes of polyethylene in blown films with different pro-oxidants. Polimeros: Ciência e Tecnologia, 31(3), e2021029. https://doi.org/10.1590/0104-1428.20210058

\section{Introduction}

The use of polymeric materials has been growing worldwide since the 1940s, replacing the use of metals, ceramics and wood in many industrial branches ${ }^{[1-3]}$. Parallel to this, a major environmental problem regarding the use of this class of materials arises: the accumulation of plastic waste in the environment (soil, rivers and oceans) due to incorrect and unconscious disposal, especially of disposable items, such as plastic bags, sacks, cups and bottles ${ }^{[3-5]}$. Due to their low specific masses, easier processing and low cost, petrochemical resins are the most widely used and are also the most difficult to degrade, including $\mathrm{PE}^{[6-10]}$, which plays an important role in the largest volume of plastic waste.

An alternative to solve the environmental problem would be the use of biodegradable polymers, which are macromolecules that can be cleaved by the action of biological enzymes of microorganisms (fungi, bacteria and algae) and subsequently used as nutrients for the growth of colonies, provided in the appropriate environmental conditions ${ }^{[11,12]}$. Thus, biodegradable polymers are returned to the environment as gaseous compounds and salts, such as $\mathrm{CO}_{2}, \mathrm{H}_{2} \mathrm{O}, \mathrm{CH}_{4}$, depending on the presence or absence of oxygen, in a process called mineralization ${ }^{[13]}$. Biodegradable polymers, however, are more expensive and difficult to process, which hinders their use when compared to petrochemical resins. Besides this, when they are low cost, they are not applicable to the required purpose, due to the absence of some property, generally mechanical ${ }^{[14]}$.

Another, more viable option would be the use of oxobiodegradable polymers, which are petrochemical resins processed with a pro-oxidant additive ${ }^{[15-17]}$. Pro-oxidant additives are responsible for favouring the abiotic degradation of the polymer, mainly by thermooxidation and photodegradation, with production of oxygenated fragments of lower molar mass that can be assimilated by microorganisms, a biotic process $^{[18-20]}$. In general, they are organic salts of transition metals, mainly stearates of $\mathrm{Fe}, \mathrm{Co}$ and $\mathrm{Mn}^{[20-25]}$. But organic pro-oxidants have been investigated, such as benzoin, which showed promising results in the abiotic degradation of polypropylene (PP) $)^{[26]}$ and $\mathrm{PE}^{[27]}$.

However, during polymer processing, as in the tubular extrusion process, the polymer is subjected to high shear rates and high temperatures when passing through the barrel, which can be initiators of the degradation process that, in the presence of $\mathrm{O}_{2}$ from air, can be called oxidative thermomechanical degradation. The present work is aimed at evaluating how the presence of pro-oxidant additives, one based on organic salts of transition metals $\left(\mathrm{d} 2 \mathrm{w}^{\mathrm{TM}}\right)$ and another totally organic (benzoin), influence the thermomechanical oxidative degradation of $\mathrm{PE}$ during processing by tubular extrusion to obtain films. The films were evaluated by 
dilute solution viscosimetry (DSV), with determination of viscosity average molar mass; Fourier-transform infrared spectroscopy (FTIR) and carbonyl index determination; flow index (MFI); contact angle and scanning electron microscopy (SEM).

\section{Materials and Methods}

\subsection{Materials}

High density polyethylene (HDPE) grade HE-150, with MFI of $1.0 \mathrm{~g} / 10 \mathrm{~min}\left(190{ }^{\circ} \mathrm{C} / 2.16 \mathrm{~kg}\right)$, and low density polyethylene (LDPE) grade EB-853/72, with MFI of $2.7 \mathrm{~g} /$ $\min \left(190^{\circ} \mathrm{C} / 2.16 \mathrm{~kg}\right)$, both produced by Braskem (Brazil), were used in this work. $\mathrm{d} 2 \mathrm{w}^{\mathrm{TM}}$ pro-oxidant additive in masterbatch form with low density polyethylene (LDPE) as a base polymer, produced by Symphony Environmental (United Kingdom). Benzoin with a purity grade above 99\%, produced by Merck KGaG (Germany). Decahydronaphthalene (Decalin) produced by Neon.

\subsection{Obtaining films by tubular extrusion}

According to Table 1, the HDPE and LDPE blend, in mass proportion of 90 and $10 \%$, respectively, was processed without and with $1 \mathrm{wt} . \%$ of pro-oxidants. The mixture was properly homogenized for processing.

The blown films, with an average thickness of $30 \mu \mathrm{m}$, were obtained by tubular extrusion in a Seibt (Brazil) singlescrew extruder, model ES 35-FR, with 5 heating zones, using the following temperature profile: $120 / 150 / 175 / 185 / 210^{\circ} \mathrm{C}$, from zones 1 (feed) to 5 (die).

\subsection{Characterization}

\subsubsection{Dilute Solution Viscosimetry (DSV) and Viscosity Average Molar Mass $(\overline{\boldsymbol{M v}})$}

In determining the viscosity average molar mass $(\overline{\boldsymbol{M v}})$, the dilute solution viscosimetry technique was used. Five PE solutions were prepared at concentrations of $0.2,0.4$, $0.6,0.8$ and $1.0 \mathrm{~g} / \mathrm{dL}$ for each film analysed, using decalin as solvent. The solutions were obtained, one by one, by determining the mass needed to prepare $25 \mathrm{ml}$ of each of the concentrations mentioned. The dissolution of the polymer took place under stirring and at $140^{\circ} \mathrm{C}$ for one hour. The viscosities of the solutions were measured in a CannonFenske viscometer $\left(\mathrm{n}^{\circ} 50\right)$ with an internal capillary diameter of $0.44 \mathrm{~mm}$. The procedures were carried out according to ASTM D445 and ASTM D446. The analyses were performed with the viscometer immersed in a thermostatic silicone oil bath of SOLAB brand, Model SL 150, at $135.0 \pm 0.1^{\circ} \mathrm{C}^{[28]}$.

First, the relative viscosities were calculated. Subsequently, the reduced specific $\left(\eta_{\text {esp }} / C\right)$ and inherent viscosities $\left(\ln \eta_{\text {rel }} / C\right)$

Table 1. Mass composition of the HDPE/LDPE films.

\begin{tabular}{|c|c|c|c|}
\hline Sample & $\begin{array}{c}\text { HDPE/LDPE } \\
(90 / 10)(\text { wt. } \%)\end{array}$ & $\begin{array}{l}\text { Benzoin } \\
\text { (wt. \%) }\end{array}$ & $\begin{array}{l}\text { d2w } \\
\text { (wt. \%) }\end{array}$ \\
\hline PE_Pure & 100 & - & - \\
\hline PE_OM & 99 & - & 1 \\
\hline PE_ONM & 99 & 1 & - \\
\hline
\end{tabular}

of each one of the solutions were determined. Plotting the graphs of such viscosities versus concentration, the intrinsic viscosity of the PE used in the preparation of the solutions was determined, from the extrapolation of the straight lines obtained by linear regression when the concentration tends to zero. The values found for the two straight lines tend to the same value and, for this reason, their average was used as intrinsic viscosity $([\eta])$. For the determination of $\overline{M v}$ of PE, the Mark-Houwink-Sakurada equation was used, which

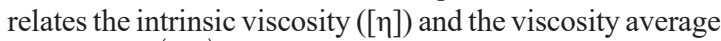
molar mass $(\overline{\boldsymbol{M v}})$, as presented in Equation 1:

$$
[\eta]=k \cdot(\overline{\boldsymbol{M v}})^{a}
$$

The $\alpha$ and $\mathrm{K}$ constants were 0.7 and $62 \times 10^{-5} \mathrm{dL} / \mathrm{g}$, respectively ${ }^{[28]}$. The films evaluated are made of a mixture of HDPE and LDPE, i.e., both PE. As per the literature reference, the viscosimetric constants used are for $\mathrm{PE}$, without distinction among its variations (whether HDPE, LDPE or LLDPE, for example).

\subsubsection{Melt Flow Index (MFI)}

The tests for determining the PE flow index of HDPE/ LDPE films with and without pro-oxidant additives were performed in the CEAST modular MeltFlow plastomer equipment, Model 7026.000, according to method A of ASTM D1238. The conditions used were $190^{\circ} \mathrm{C} / 2.16 \mathrm{~kg}$, with a residence time of 420 seconds and time between cuts of 60 seconds, with a total test time of 900 seconds for each sample.

\subsubsection{Fourier Transform Infrared Spectroscopy (FTIR) and Carbonyl Index (Cl)}

To investigate the changes in the chemical structure of the films, especially the appearance of new functional groups due to oxidation, the FTIR analysis was performed in Perkin Elmer equipment, Frontier model, according to ASTM E1131. The films were evaluated in the ATR (Total Attenuated Reflectance) mode and the spectra obtained at a controlled ambient temperature of $25^{\circ} \mathrm{C}$, air humidity of $30 \%$ and in an absorption region ranging from 4000 to $650 \mathrm{~cm}^{-1}$, with 10 scans for each sample analysed. From the spectra, the carbonyl indices (CI) were calculated. The poorly variable absorption band peak was adopted as that at $1463 \mathrm{~cm}^{-1[29]}$, and the limits between 1468 and $1450 \mathrm{~cm}^{-1}\left(\mathrm{~A}_{1468-1450}\right)$ were integrated. The absorption peaks of carbonyls adopted to verify the degree of PE oxidation were of esters and carboxylic acids (1300-1050 $\left.\mathrm{cm}^{-1}\right)$ and lactones $\left(1780-1770 \mathrm{~cm}^{-1}\right)$, and the limits between the adopted bands were integrated, named $\mathrm{A}_{1300-1050}$ and $\mathrm{A}_{1780-1770}{ }^{[25,30]}$, respectively. The CI was calculated from Equation 2:

$$
C I=\left(A_{1300-1050}+A_{1780-1770}\right) / A_{1468-1450}
$$

\subsubsection{Contact angle}

The contact angle test was performed using deionized water as the liquid, according to ASTM D7334-08. The analysis allows the determination of the substrate (film) hydrophilicity or hydrophobia. For each film, 10 repetitions were made, in 
which drops of water were placed on the surface. The images were obtained from a Knup microscope, model Kp-8012, and the contact angles determined from the Surftens 4.3 software for 3 seconds and 3 minutes.

\subsubsection{Scanning Electron Microscopy (SEM)}

The surface morphologies of the samples were obtained by scanning electron microscopy soon after processing by tubular extrusion, in a Jeol instrument, model JSM6510LV. The films were metallized with gold in a standard procedure in the Denton Caccum metallizer, model Desk. Micrographs were obtained with electron beams at $10 \mathrm{kV}$ energy and magnifications of 1500 and 5000x.

\section{Results and Discussions}

After processing, the samples were characterized to evaluate the influence of the pro-oxidant on the process of thermomechanical oxidative degradation of PE during extrusion of the blown films.

\subsection{Evaluation of $(\overline{\mathbf{M v}})$ and MFI}

The intrinsic viscosity ([ๆ]) of the PE was determined for each of the samples and is shown in Table 2.

From the Mark-Howink-Sakurada equation (Equation 1), the $\overline{\boldsymbol{M v}}$ of the PE in the evaluated films were determined, presented in Figure 1-a. In Figure 1-b, the MFI results of the evaluated films are presented.

Table 2. Intrinsic viscosity ([ๆ]) of PE in the samples evaluated.

\begin{tabular}{|c|c|c|c|}
\hline Sample & {$[\eta]_{1}^{*}$} & {$[\eta]_{2}^{* *}$} & {$[\eta]_{f}^{* * *}$} \\
\hline PE_Pure & 1.5185 & 1.5651 & 1.5418 \\
\hline PE_OM & 1.3812 & 1.4873 & 1.4342 \\
\hline PE ONM & 1.2376 & 1.4336 & 1.3356 \\
\hline
\end{tabular}

*obtained of graph $\eta_{\text {sp.red }}$ versus $C$; ** obtained graph $\eta_{\text {inehr }}$ versus $C$; $* * *$ average intrinsic viscosity of $[\eta]_{1}$ and $[\eta]_{2}$.
In Figure 1-a is possible to observe a decrease of $\overline{\boldsymbol{M v}}$ of the PE in the films extruded with the pro-oxidants if compared to the film without additives. The presence of the additives led to higher rates of chain scission and, consequently, a reduction in molar mass, indicating a greater degradation process of the polymer ${ }^{[31,32]}$. The PE scission process was more intense in the presence of benzoin than for $\mathrm{d} 2 \mathrm{w}^{\mathrm{TM}}$, since the PE molar mass reduction in the PE_ONM film was higher than in the PE_OM film.

The MFI values, in Figure 1-b, indicate that there is a greater difficulty in the flow of the molten PE macromolecules in the PE_Pure film, possibly due to their larger size compared to the films containing pro-oxidants. The PE_ONM film containing benzoin, on the other hand, showed higher MFI, indicating higher fluidity and lower viscosity of the molten polymer, compatible with the lower $\overline{\boldsymbol{M} \boldsymbol{v}}$ of the sample and for which there is higher mobility, possibly due to the presence of smaller chains size and less likelihood of entanglement. The PE_OM film showed MFI with intermediate value, compatible with its $\overline{\boldsymbol{M v}}$.

It can be seen that there is a coherent correlation between the $\overline{\boldsymbol{M v}}$ and the MFI, since the reduction of the $\overline{\boldsymbol{M} \boldsymbol{v}}$ is followed by an increase in MFI, indicating with the PE with smaller chains size has higher flow when melted, observed for the PE_ONM film. The opposite is also true, i.e., the PE in the PE_Pure sample, with higher $\overline{\boldsymbol{M} \boldsymbol{v}}$, has the lowest flow when melted, hampered by the larger size of the polymer chains.

\subsection{FTIR}

Figure 2-a shows the FTIR spectra, between the 2000 and $1500 \mathrm{~cm}^{-1}$ bands, of the PE films just after processing by tubular extrusion. It is possible to observe that all samples present peaks between 1780 and $1700 \mathrm{~cm}^{-}$ ${ }^{1}$, which indicates that the PE, in all samples, suffered oxidation during processing, with formation of oxidized products, such as esters, ketones, aldehydes, lactones and carboxylic acids ${ }^{(25,34)}$. Visually, the PE_Pure film presents lower peaks, mainly at 1780 and $1712^{-} \mathrm{cm}^{-1}$. The PE_OM

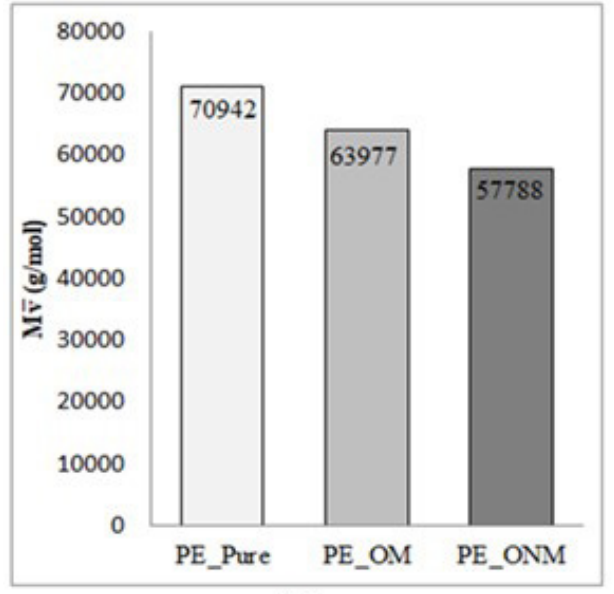

(a)

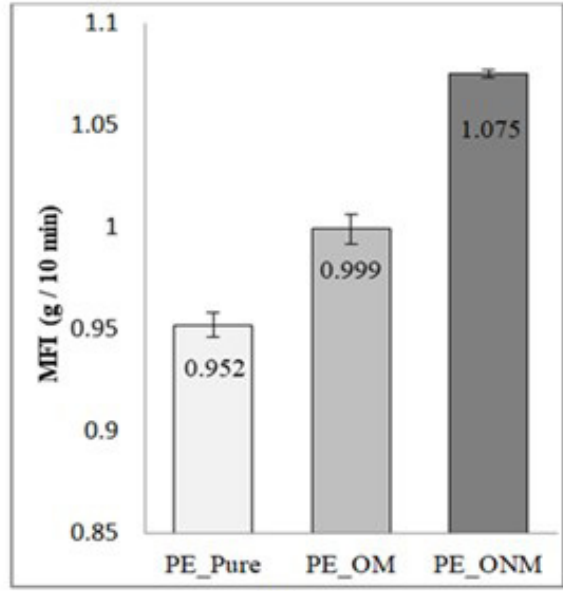

(b)

Figure 1. Properties of the evaluated samples: (a) $\overline{\boldsymbol{M v}}$, (b) MFI. 
film presents well defined peaks at 1712, 1723, 1730 and $1780 \mathrm{~cm}^{-1}$, indicating that the $\mathrm{d} 2 \mathrm{w}^{\mathrm{TM}}$ additive favoured autooxidation. The PE_ONM film presents a clear peak at $1780 \mathrm{~cm}^{-1}$, suggesting that benzoin favoured PE autooxidation, however, the peak at $1723 \mathrm{~cm}^{-1}$ is overlap with the $1730 \mathrm{~cm}^{-1}$ peak, emphasizing that benzoin has a ketone group in its structure and, for this reason, the production of fragments containing esters and carboxylic acids groups was considered, observable in Figure 2-b, FTIR spectra, between the 1400 and $1000 \mathrm{~cm}^{-1}$, in which it is possible to observe that there is production of these oxygenated fragments in all samples. Visually, the PE ONM film presents peak broadening between 1300 and $1250 \mathrm{~cm}^{-1}$, as well as between 1150 and $1100 \mathrm{~cm}^{-1}$, when compared to the other two films, which suggests a higher degree of oxidation. The PE_OM film, when compared to PE_Pure film, presents wider and deeper peak between
1100 and $1050 \mathrm{~cm}^{-1}$. However, it was decided to discuss the oxidation degree of the samples by the CI evaluation.

Using Equation 2 and the Origin 8.5.1 software, the CI values for the samples were calculated and are shown in Figure 3. The different CI values indicate unequal degrees of oxidation of the PE in the samples during the extrusion process, favoured by exposure to high temperatures and high shear rates in the presence of $\mathrm{O}_{2}$ from the air ${ }^{[33,34]}$.

In the case of the samples evaluated, the presence of carbonyl groups is evident in all, indicating that the PE suffered oxidation, producing, among others, carboxylic acids, esters, and lactones ${ }^{[15,19,20,34]}$. However, the CI value is higher for PE_ONM and PE_OM. Comparing only the CI values, benzoin and $\mathrm{d} 2 \mathrm{w}^{\mathrm{TM}}$ showed equal efficiency in accelerating PE autooxidation by thermooxidation, since the index values are similar.

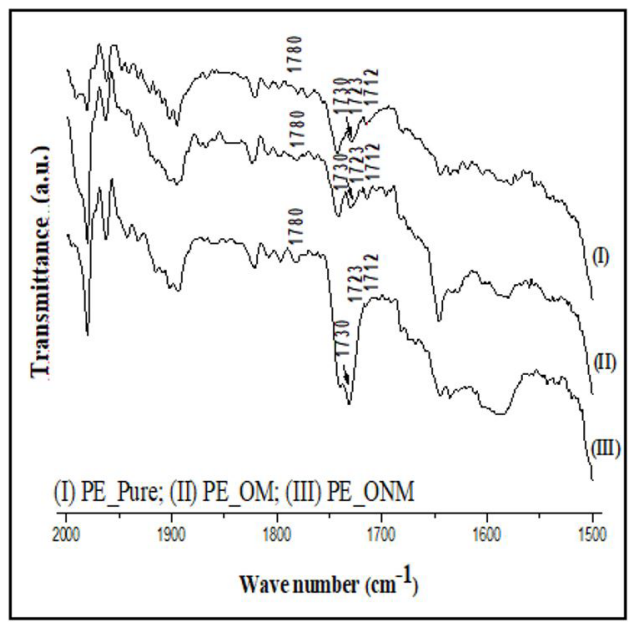

(a)

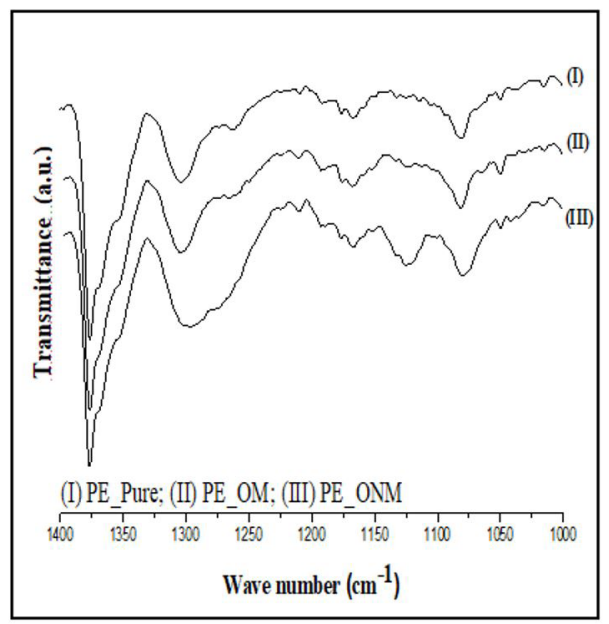

(b)

Figure 2. FTIR spectra of the evaluated samples: (a) between 2000 and $1500 \mathrm{~cm}^{-1}$, (b) between 1400 and $1000 \mathrm{~cm}^{-1}$.

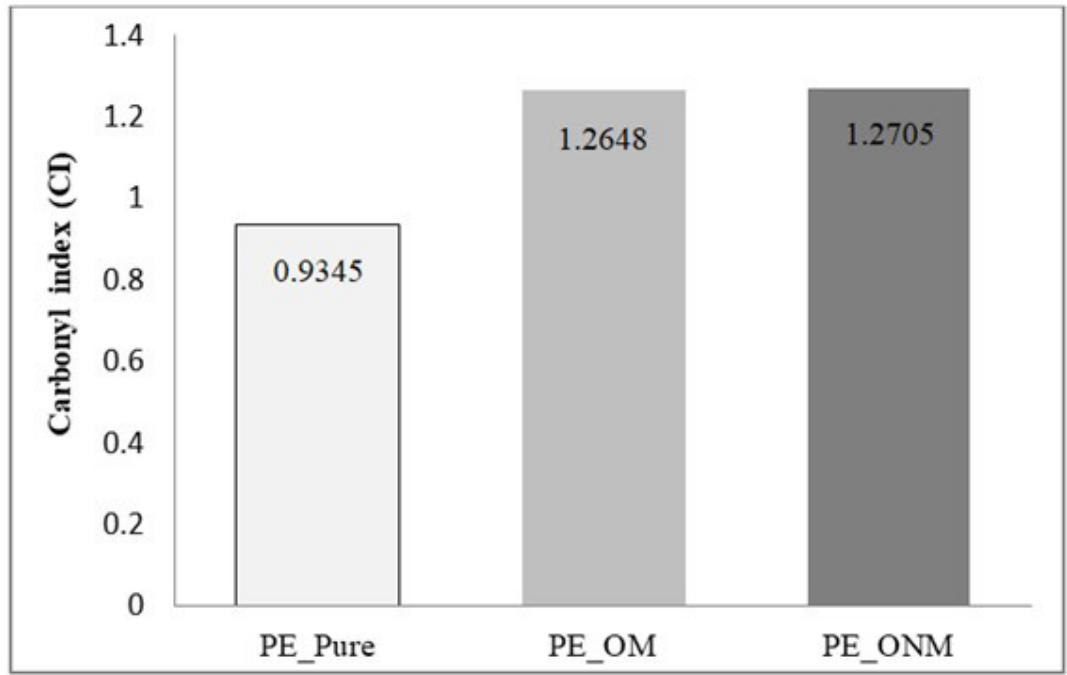

Figure 3. Carbonyl index of the samples. 


\subsection{Contact angle}

Another way to confirm the presence of functional groups is through the contact angle. Figure 4 shows the images of the water droplets on the surface of the films, in which it is possible to visualize the differences between the contours of the droplets and the contact angles for each of the films. It can be seen that the droplet on the PE_ONM sample (Figure 4-c) is more spread on the surface than the others, indicating that its surface is more hydrophilic.

The average surface contact values of the films of the evaluated samples are shown in Figure 5. The results found indicated that the PE_Pure film is the most apolar, with the largest contact angle, consistent with its low oxidation rate, if considered the CI value. The PE OM film, is the second most apolar, with small reduction of the contact angle value, if compared to the PE_Pure film.

The reduction of the contact angle is possibly due to the greater insertion of carbonyls in the polymer chain, which changed its polarity. The PE ONM film showed a marked reduction in the contact angle value compared to the other two films. Besides the insertion of carbonyl groups, the film also presented a higher concentration of hydroxyls $(-\mathrm{OH})$, capable of establishing hydrogen bonds with water and reducing the contact angle presenting, therefore, the lowest value. The contact angle reduction indicates the PE degradation process in films additivated with pro-oxidants, with insertion of hydrophilic functional groups ${ }^{[35]}$. Benzoin, besides catalyzing the degradation of $\mathrm{PE}$, altered the film surface by the insertion of hydroxyls in its structure.

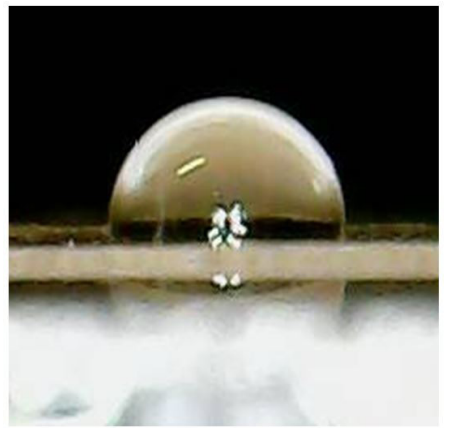

(a)

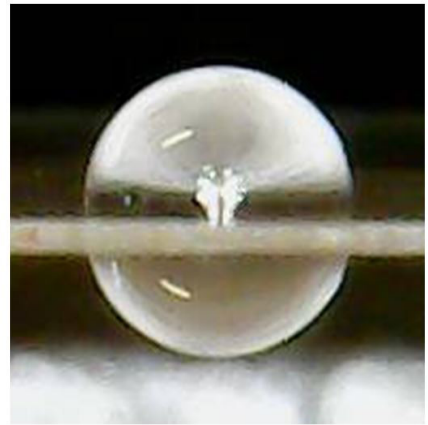

(b)

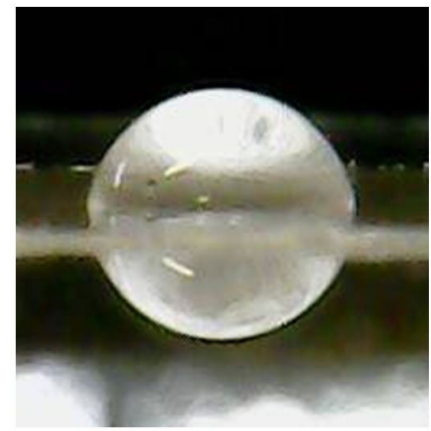

(c)

Figure 4. Images of deionized water droplets arranged on the analysed films: (a) PE_Pure; (b) PE_OM; (c) PE_ONM.

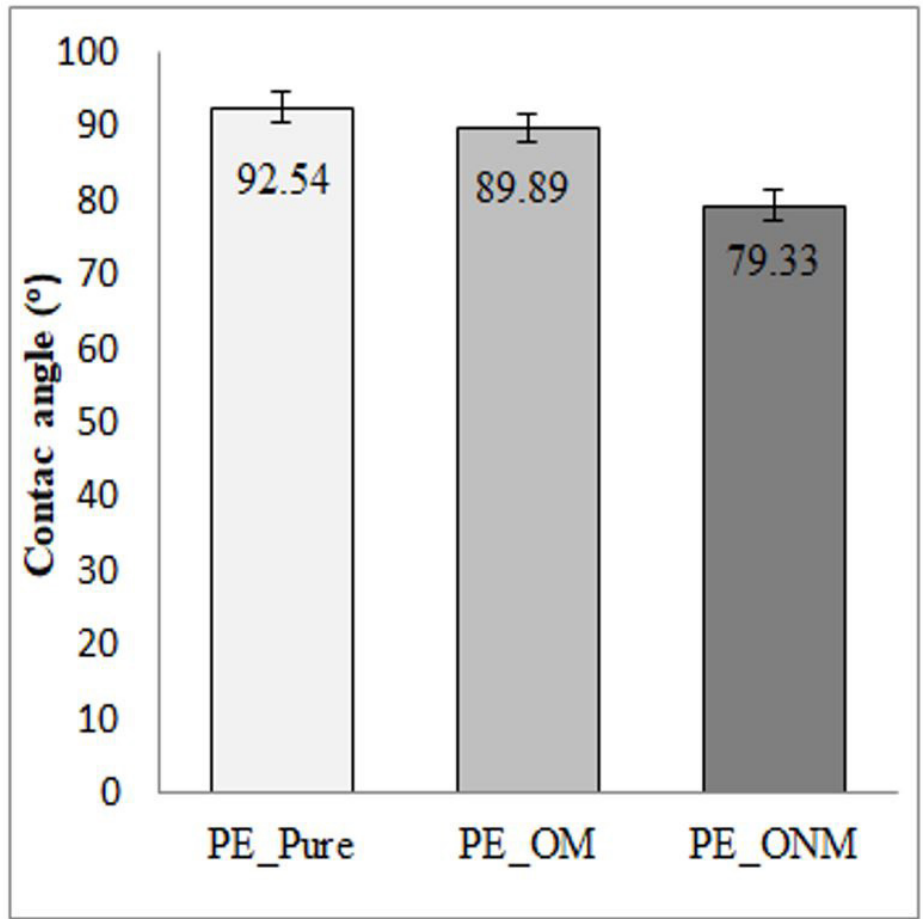

Figure 5. Contact angle of the evaluated samples. 


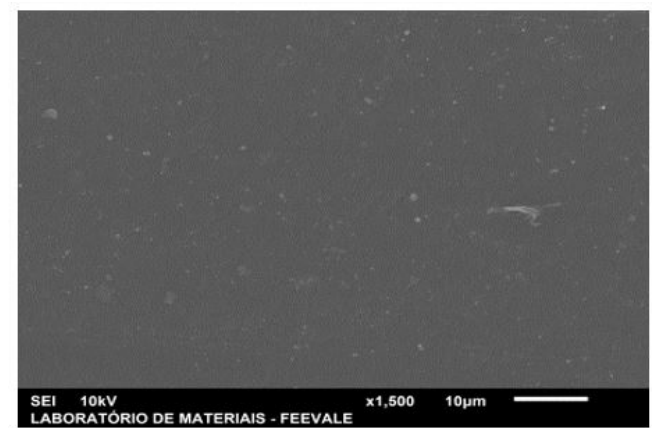

(a)

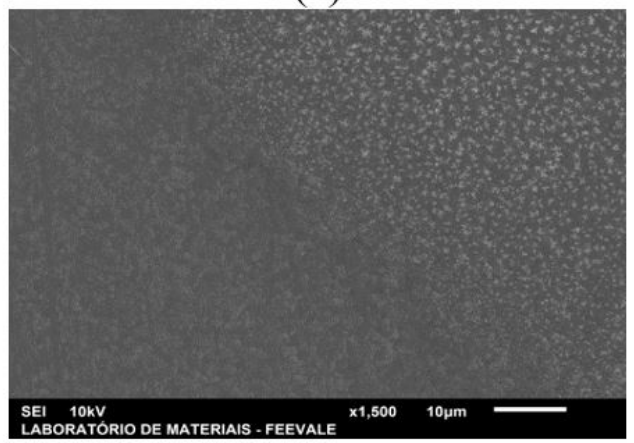

(c)

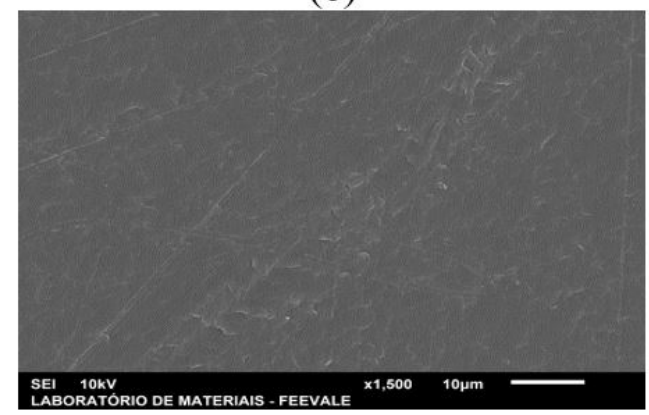

(e)

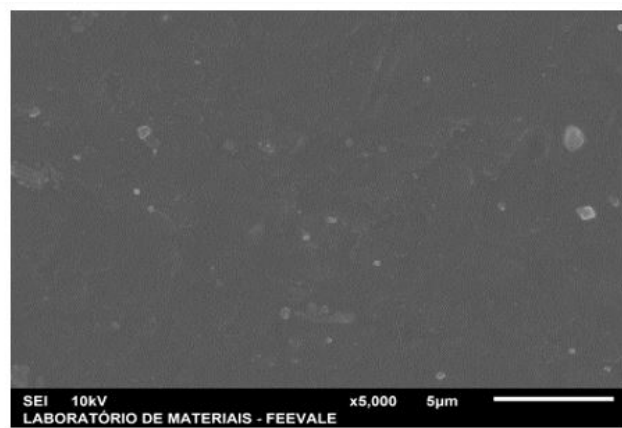

(b)

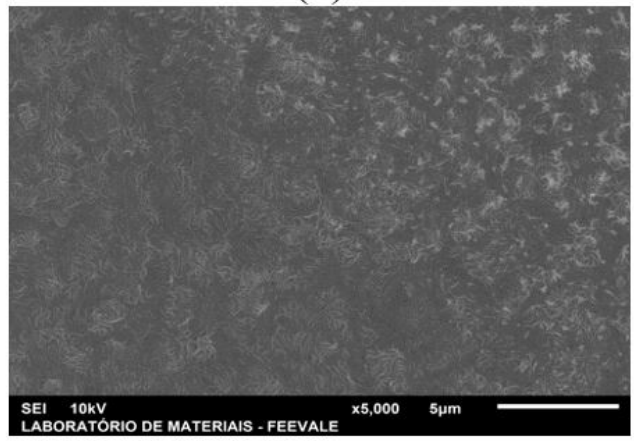

(d)

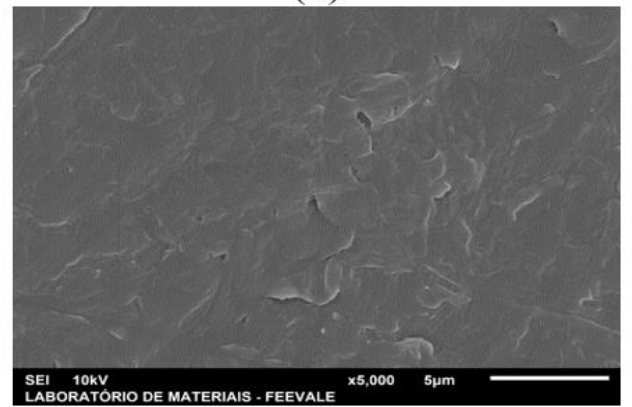

(f)

Figure 6. SEM images of the samples: (a) PE_Pure - 1500 x; (b) PE_Pure - 5000 x; (c) PE_OM - 1500 x; (d) PE OM - 5000 x; (e) PE_ONM - $1500 \mathrm{x}$; (f) PE_ONM - $5000 \mathrm{x}$.

\subsection{SEM}

The micrographs obtained to evaluate the surface morphology of the samples evaluated are presented in Figure 6 and in them it is possible to observe differences that indicate that the processing of $\mathrm{PE}$, with and without pro-oxidant additives, leads to structural changes in the extruded films.

The film PE_Pure presents the highest surface homogeneity, while the film PE_ONM presents irregularities, possibly due to the presence of the polar chemical agent, benzoin, which hindered a better dispersion of the apolar polymer. The PE_OM film presents morphological variations with the appearance of agglomerations, which not indicate a total dissolution of the masterbatch containing the additive, whose processing took place in a single-screw extruder. Initially, these alterations only point out that the different organizations of the macromolecules may favour an increase in the fragility of the films for subsequent uses.

\section{Conclusions}

The tubular extrusion process is characterized by exposure of the polymer to high shear rates associated with high temperatures, and in this study, PE with pro-oxidants had its degradation accelerated, increasing the rate of scission and oxidation of the macromolecules. The benzoin pro-oxidant accelerates this degradation more markedly compared to the $\mathrm{d} 2 \mathrm{w}^{\mathrm{TM}}$ additive, as it led to a greater reduction in the $\boldsymbol{M v}$ of the polymer evaluated. The structural changes in PE observed in this work need to be considered when using pro-oxidant additives to obtain oxybiodegradable PE, since they can alter important characteristics of a plastic artifact produced from it, such as disposable bags, reducing its shelf life. 


\section{Acknowledgements}

Thanks to The National Council for Scientific and Technological (CNPq) for the financial support. Thanks to Federal Institute of Rio Grande do Sul (IF/RS) - Campus Farroupilha for carrying out FTIR analyses. Thanks to Feevale University for the SEM analyses.

\section{References}

1. Thompson, R. C., Moore, C. J., vom Saal, F. S., \& Swan, S. H. (2009). Plastics, the environment and human health: current consensus and future trends. Philosophical Transactions of the Royal Society of London. Series B, Biological Sciences, 364(1526), 2153-2166. http://dx.doi.org/10.1098/rstb.2009.0053. PMid:19528062.

2. Vázquez-Morillas, A., Beltrán-Villavicencio, M., AlvarezZeferino, J. C., Osada-Velázquez, M. H., Moreno, A., Martínez, L., \& Yañez, J. M. (2016). Biodegradation and ecotoxicity of polyethylene films containing pro-oxidant additive. Journal of Polymers and the Environment, 24(3), 221-229. http://dx.doi. org/10.1007/s10924-016-0765-8.

3. Silva, E. A., \& Moita Neto, J. M. (2015). Environmental impacts the production of polyethylene bottles in a Teresina-PI factory. Polímeros: Ciência e Tecnologia, 25(No. esp.), 59-67. http:// dx.doi.org/10.1590/0104-1428.1949.

4. Vasconcelos, Y. (2019). Planeta plástico. Pesquisa FAPESP, 281, 18-24. Retrieved in 2021, August 1, from https://revistapesquisa. fapesp.br/planeta-plastico/

5. Thompson, R. C., Swan, S. H., Moore, C. J., \& vom Saal, F. S. (2009). Our plastic age. Philosophical Transactions of the Royal Society of London. Series B, Biological Sciences, 364(1526), 1973-1976. http://dx.doi.org/10.1098/rstb.2009.0054. PMid:19528049.

6. Silva, E. A., \& Moita, J. M., No. (2016). Possibilities for environmental improvements in the polyethylene recycling process. Polimeros: Ciência e Tecnologia, 26(No. esp.), 49-54. http://dx.doi.org/10.1590/0104-1428.1954.

7. Koutny, M., Lemaire, J., \& Delort,A.-M. (2006). Biodegradation of polyethylene films with prooxidant additives. Chemosphere, 64(8), 1243-1252. http://dx.doi.org/10.1016/j.chemosphere.2005.12.060. PMid: 16487569 .

8. Lucas, N., Bienaime, C., Belloy, C., Queneudec, M., Silvestre, F., \& Nava-Saucedo, J.-E. (2008). Polymer biodegradation: mechanisms and estimation techniques. Chemosphere, 73(4), 429-442. http://dx.doi.org/10.1016/j.chemosphere.2008.06.064. PMid: 18723204

9. Ammala, A., Bateman, S., Dean, K., Petinakis, E., Sangwan, P., Wong, S., Yuan, Q., Yu, L., Patrick, C., \& Leong, K. H. (2011). An overview of degradable and biodegradable polyolefins. Progress in Polymer Science, 36(8), 1015-1049. http://dx.doi. org/10.1016/j.progpolymsci.2010.12.002.

10. Passos, T. M., Marconato, J. C., \& Franchetti, S. M. M. (2015). Biodegradation of films of low density polyethylene (LDPE), poly(hidroxibutyrate-co-valerate) (PHBV), and LDPE/PHBV (70/30) blend with Paecilomyces variotii. Polimeros: Ciência e Tecnologia, 25(1), 29-34. http://dx.doi.org/10.1590/01041428.1432

11. Rosa, D. S., \& Pantano, R., Fo. (2003). Biodegradabilidade - um ensaio com polímeros. Brazil: Moara.

12. Franchetti, S. M. M., \& Marconato, J. C. (2006). Polímeros biodegradáveis - uma solução parcial para diminuir a quantidade dos resíduos plásticos. Quimica Nova, 29(4), 811-816. http:// dx.doi.org/10.1590/S0100-40422006000400031.

13. Luckachan, G. E., \& Pillai, C. K. S. (2011). Biodegradable polymers - A review on recent trends and emerging perspectives.
Journal of Polymers and the Environment, 19(3), 637-676. http://dx.doi.org/10.1007/s10924-011-0317-1.

14. Siracusa, V., Rocculi, P., Romani, S., \& Rosa, M. D. (2008). Biodegradable polymer for food: a review. Trends in Food Science \& Technology, 19(12), 634-643. http://dx.doi.org/10.1016/j. tifs.2008.07.003

15. Ojeda, T. F. M., Dalmolin, E., Forte, M. M. C., Jacques, R. J. S., Bento, F. M., \& Camargo, F. A. O. (2009). Abiotic and biotic degradation of oxo-biodegradable polyethylenes. Polymer Degradation \& Stability, 94(6), 965-970. http://dx.doi org/10.1016/j.polymdegradstab.2009.03.011.

16. Sen, S. K., \& Raut, S. (2015). Microbial degradation of low density polyethylene (LDPE): a review. Journal of Environmental Chemical Engineering, 3(1), 462-473. http:// dx.doi.org/10.1016/j.jece.2015.01.003.

17. Santos, A. S. F., Freire, F. H. O., Costa, B. L. N., \& Manrich, S. (2012). Sacolas plásticas: destinações sustentáveis e alternativas de substituição. Polímeros: Ciência e Tecnologia, 22(3), 228 237. http://dx.doi.org/10.1590/S0104-14282012005000036.

18. Chiellini, E., Corti, A., D’Antone, S., \& Baciu, R. (2006). Oxo-biodegradable carbon backbone polymers - Oxidative degradation of polyethylene under accelerated test conditions. Polymer Degradation \& Stability, 91(11), 2739-2747. http:// dx.doi.org/10.1016/j.polymdegradstab.2006.03.022.

19. Liu, X., Gao, C., Sangwan, P., Yu, L., \& Tong, Z. (2014). Accelerating the degradation of polyolefins through additives and blending. Journal of Applied Polymer Science, 131(18), 9001-9015. http://dx.doi.org/10.1002/app.40750.

20. Reddy, M. M., Gupta, R. K., Gupta, R. K., Bhattacharya, S. N., \& Parthasarathy, R. (2008). Abiotic oxidation studies of oxo-biodegradable polyethylene. Journal of Polymers and the Environment, 16(1), 27-34. http://dx.doi.org/10.1007/s10924008-0081-z.

21. Roy, P. K., Surekha, P., Raman, R., \& Rajagopal, C. (2009). Investigating the role of metal oxidation state on the degradation behavior of LDPE. Polymer Degradation \& Stability, 94(7), 1033 1039. http://dx.doi.org/10.1016/j.polymdegradstab.2009.04.025.

22. Jakubowicz, I. (2003). Evaluation of degradability of biodegradable polyethylene (PE). Polymer Degradation \& Stability, 80(1), 39-43. http://dx.doi.org/10.1016/S0141-3910(02)00380-4.

23. Corti, A., Muniyasamy, S., Vitali, M., Imam, S. H., \& Chiellini, E. (2010). Oxidation and biodegradation of polyethylene films containing pro-oxidant additives: synergistic effects of sunlight exposure, thermal aging and fungal biodegradation. Polymer Degradation \& Stability, 95(6), 1106-1114. http:// dx.doi.org/10.1016/j.polymdegradstab.2010.02.018.

24. Vogt, N. B., \& Kleppe, E. A. (2009). Oxo-biodegradable polyolefins show continued and increased thermal oxidative degradation after exposure to light. Polymer Degradation \& Stability, 94(4), 659-663. http://dx.doi.org/10.1016/j. polymdegradstab.2009.01.002.

25. Babetto, A. S., Agnelli, J. A. M., \& Bettini, S. H. P. (2015). Evaluation of the pro-degradant systems in the thermooxidative degradation of HDPE. Polímeros: Ciência e Tecnologia, 25(No. esp.), 68-76. http://dx.doi.org/10.1590/0104-1428.2022.

26. Montagna, L. S., Catto, A. L., Forte, M. M. C., Chiellini, E., Corti, A., Morelli, A., \& Santana, R. M. C. (2015). Comparative assessment of degradation in aqueous medium of polypropylene films doped with transition metal free (experimental) and transition metal containing (commercial) pro-oxidant/prodegradant additives after exposure to controlled UV radiation. Polymer Degradation \& Stability, 120, 186-192. http://dx.doi. org/10.1016/j.polymdegradstab.2015.06.019.

27. Rosa, T. P. S. (2019). Polietileno modificado com pró-degradante orgânico para aplicação em embalagens flexíveis (Master's Thesis). Universidade Federal do Rio Grande do Sul, Porto Alegre. 
28. Brandup, J., Immergut, E. H., \& Grulke, E. A. (2009). Polymer Handbook. 2nd ed. New York: Wiley-Interscience Publication.

29. Gulmine, J. V., Janissek, P. R., Heise, H. M., \& Akcelrud, L. (2002). Polyethylene characterization by FTIR. Polymer Testing, 21(5), 557-563. http://dx.doi.org/10.1016/S0142-9418(01)00124-6.

30. Sugimoto, M., Shimada, A., Kudoh, H., Tamura, K., \& Seguchi, T. (2013). Product analysis for polyethylene degradation by radiation and thermal ageing. Radiation Physics and Chemistry, 82, 69-73. http://dx.doi.org/10.1016/j.radphyschem.2012.08.009.

31. Albertsson, A.-C., Erlandsson, B., Hakkarainen, M., \& Karlsson, S. (1998). Molecular weight changes and polymeric matrix changes correlated with the formation of degradation products in biodegradable polyethylene. Journal of Environmental Polymer Degradation, 6(4), 187-195. http:// dx.doi.org/10.1023/A:1021873631162.

32. Khajehpour-Tadavani, S., Nejabat, G.-R., \& Mortazavi, S. M. M. (2018). Oxo-biodegradability of high-density polyethylene films containing limited amount of isotactic polypropylene. Journal of Applied Polymer Science, 135(6), 45843. http:// dx.doi.org/10.1002/app.45843.
33. Agnelli, J. A. M., \& Chinelatto, M. A. (1992). Degradação de polipropileno: aspectos teóricos e recentes avanços em sua estabilização. Polímeros: Ciência e Tecnologia, 2(3), 27-31. Retrieved in 2021, August 1, from https://revistapolimeros. org.br/journal/polimeros/article/588371317f8c9d0a0c8b4792

34. Gardette, M., Perthue, A., Gardette, J.-L., Janecska, T., Földes, E., Pukanszky, B., \& Therias, S. (2013). Photo and thermaloxidation of polyethylene: comparison of mechanisms and influence of unsaturation content. Polymer Degradation \& Stability, 98(11), 2383-2390. http://dx.doi.org/10.1016/j. polymdegradstab.2013.07.017.

35. Muthukumar, T., Aravinthan, A., \& Mukesh, D. (2010). Effect of environment on the degradation of starch and pro-oxidant blended polyolefins. Polymer Degradation \& Stability, 95(10), 1988-1993. http://dx.doi.org/10.1016/j. polymdegradstab.2010.07.017.

Received: Aug. 05, 2021

Revised: Oct. 07, 2021

Accepted: Oct. 25, 2021 